\title{
Compostagem de poda de árvores para uso em horta comunitária do município de Pirangi, SP
}

Anaira Denise Caramelo Silveira

Prefeitura do Município de Pirangi, anairacaramelo@yahoo.com.br Pirangi, SP, Brasil

Licania tomentosa, Syzygium jambos e Terminalia catappa

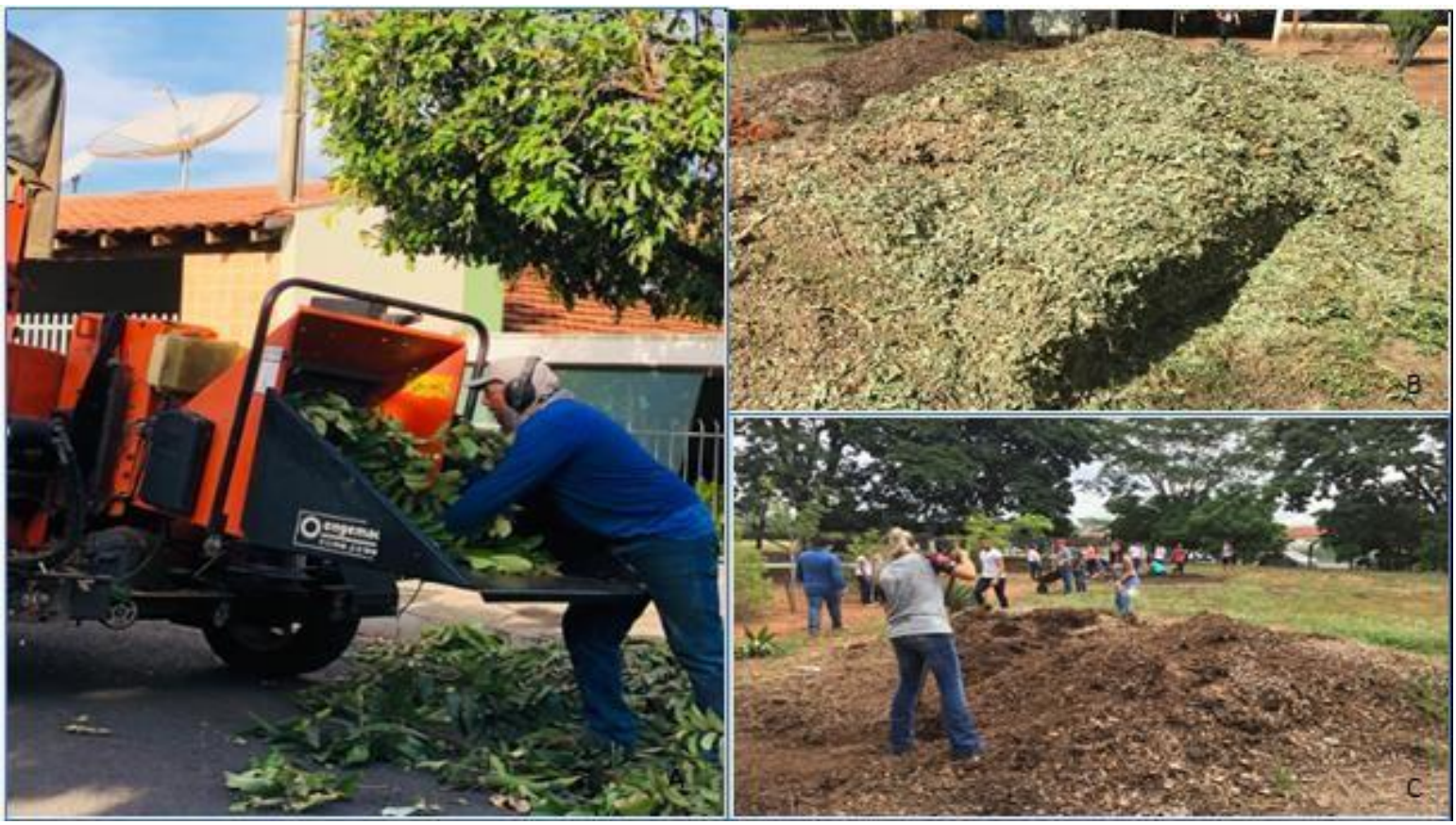

Figura: A: Poda de árvore sendo triturada por funcionário e triturador municipal; Figura: B: Poda de árvore triturada e encaminhada para a compostagem; Figura: $C$ : Composto de poda de árvore sendo utilizado para na horta comunitária.

Figure: A: Tree pruning being crushed by an official and municipal shredder; Figure: B: Pruning of the crushed tree and sent for composting; Figure: C: Tree pruning compound being used in the community garden.

RESUMO: No município de Pirangi, SP, a prefeitura dispõe de um triturador de galhos que tem auxiliado positivamente na gestão dos resíduos verdes, principalmente os advindos da arborização urbana. Após triturados, esses resíduos são dispostos em leiras aeradas para a realização da compostagem, que ao final de cerca de três meses, são direcionados para a horta comunitária, onde são reaproveitados como condicionadores de solo pela incorporação da matéria orgânica, atuando inclusive na retenção da água, cobertura do solo e estímulo ao desenvolvimento de fungos, bactérias e anelídeos benéficos ao solo. Durante a realização do projeto, são integrados alunos da rede municipal de ensino e também os participantes do Programa Jovem Agricultor do Futuro, estabelecido por meio de uma parceira entre o SENAR e a Prefeitura Municipal, com a finalidade de instruí-los sobre a importância da reutilização de resíduos, principalmente os orgânicos, tendo em vista a produção de alimentos de maneira sustentável. Além disso, os alimentos produzidos são doados aos alunos participantes do projeto e também às instituições parceiras da prefeitura, tendo em vista disseminar o projeto e também os resultados advindos.Os resultados têm permitido com que a população colabore com o processo, utilizando inclusive o composto em suas próprias hortas.

Palavras-chave: Composto; Licania tomentosa; Sustentabilidade.

realização

realização
organized by

NบTคษ

apoio
institucional

institucional

TSP

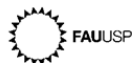

ABSTRACT: The city of Pirangi, SP, has a branch crusher that has positively helped in the management of green waste, mainly from urban afforestation. After being crushed, these residues are disposed on aerated windrows for the composting, which after about three months, are sent to the community garden, where they are reused as soil conditioners by incorporating organic matter, also acting on the retention of water, soil cover and stimulating the development of fungi, bacteria, and annelids beneficial to the soil. During the realization of the project, students from the municipal school system are integrated, as well as participants from the Young Farmer of the Future Program, established through a partnership between the SENAR and the City Hall, with the purpose of making them aware of the importance of reuse of waste, mainly organic, with a view to producing food in a sustainable manner. In addition, the food produced is donated to students participating in the project and to partner institutions of the city, with a view to disseminating the project and its results. The results have allowed the population to collaborate with the process, including using the compost in their own gardens.

Keywords: Composting; Licania tomentosa; Sustainability. 